\title{
A Note on Translations
}

Whenever POSSIBLE I have used Gregory Rabassa's translation of Paradiso (Austin: University of Texas Press, 1988). In those cases where my analysis required a more literal rendering, I have done the translation myself. In other cases I have ventured to bring Rabassa's translation closer to the original. All departures from Rabassa's translation are enclosed in brackets. Unless otherwise noted, all other translations are mine. All references to Lezama's works are to the Aguilar edition of the Obras Completas in two volumes and are given in parentheses in the text. 
THIS PAGE INTENTIONALLY LEFT BLANK 